\title{
Związki twórcze Julii Hartwig z kulturą francuską
}

Marcin Telicki 


\section{Marcin Telicki}

\section{Związki twórcze Julii Hartwig z kulturą francuską}

$\int$ eżeli ku którejś z granic umykała kulturalno-literacka myśl twórców polskich, począwszy od wieku XVII, a na polowie XX skończywszy, byla to z pewnością granica francuska. Ogromny wpływ twórczości romańskiego kręgu kulturowego na polskie dokonania literackie trafnie diagnozował Stefan Żeromski w mini-eseju, powstałym z odpowiedzi na ankietę „Les Nouvelles Littéraires” w 1924 roku:

Upodobanie świata artystycznego Polski w ogromie i całości piśmiennictwa francuskiego, zawsze bardzo znaczne, a w niektórych momentach, jak to niżej zobaczymy, ogromme - obecnie, wskutek calego splotu okoliczności, nie tylko nie maleje, lecz wzmaga się nadzwyczajnie. Każde nowe imię literackie i każde nowe wybitne dzielo budzi wśród nas żywe zainteresowanie, przechodzące częstokroć, jak wszędzie na świecie, w sférę snobizmı!.

W owym czasie nowe (czy stosunkowo nowe) były nazwiska, których część przywoluje Żeromski w swej wypowiedzi - Artur Rimbaud, Guillaume Apollinaire, Max Jacob, Pierre Reverdy, Henri Michatıx, Blaise Cendrars... Była to grupa rewolucjonistów poezji francuskiej, a poprzez medium tłumaczeń — również literatury powszechnej. Dziś — z dhuższej perspektywy historycznoliterackiej - mówi się o nich w kontekście szeroko pojętego modernizmu, znaczonego nurtami awangardowymi. Wymienieni poeci - bliscy między innymi kubizmowi i surrealizmowi - rozpoznawali bowiem obszary szczególnie istotne dla moderny. Próbowali przewartościować kwestię podıniotowości, percepcji świata materialnego, zadawali istotne pytanie o tuasadnienia dla istnienia kategorii metafizyki.

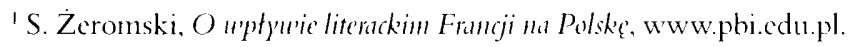


Pierwsi też przenieśli powyższe problemy z poziomu obserwacji zjawisk na poziom języka poetyckiego - wyznaczając standard dla poezji dwudziestowiecznej.

W Polsce zainteresowanie thumaczy było ogromne, przede wszystkim dzięki

doskonałym poetom, którzy w doskonałych przekładach odtwarzają poezję francuską antologicznie od czasów najdawniejszych do najostatniejszych ${ }^{2}$.

Nie brakło antologii poezji francuskiej wtedy, gdy Żeromski pisał cytowane słowa przykładem choćby antologie Karskiego, Staffa, Czernego czy Napierskiego ${ }^{3}$, oraz wiele thumaczeń i tekstów popularyzatorskich w „Wiadomościach Literackich”. Jednym z najbardziej znanych tłumaczy twórców bliskich surrealizmowi stal się Adam Ważyk. W 1947 roku wydaje on dobrze przyjętą i szeroko komentowaną Antologię uspótczesnej poezji francuskiejt. Przethumaczenie jednego z wierszy powierzyl mlodej wówczas, 26-letniej autorce, nieznanej szerszej publiczności - Julii Hartwig. Poetka wspomina wydanie Antologii... jako wielkie wydarzenie w swojej twórczej biografii:

Dokładnie pamiętam, kiedy przetłumaczyłam pierwszy wiersz francuski. To było na zamówienie Adama Ważyka (...). Wcześniej nie próbowałam thumaczyć, bowiem moja francuszczyzna wydawala mi się chwiejna. Ale tłumaczenia od razu się spodobaly Ważykowi. Nie było żadnych poprawek, a nawet w recenzji z tej antologii, czym się już clıwaliłam kilkakrotnie, Miłosz wyróżnil moje thumaczenie wiersza Cendrarsa $W$ środku śuiata. I to oczywiście bardzo mnie ośmieliło ${ }^{5}$.

Wówczas nie mogła jeszcze powtórzyć za autorem Wielkanocy' "Nou' N'm Jorku:

Niebo paryskie jest czystsze niż połyskujące od chłodu niebo zimowe,

Nigdy nie widziałem nocy bardziej gwiaździstych i bujnych niz tej wiosny,

Gdy drzewa na bulwarach są jak cienie nieba,

\footnotetext{
Ibidcm.

3. Nowakowski wymienia whask encyklopedycznym Francusko-polskic zuliqzki literickie antologie: M. G. Karski. Tęcar. Liryka fruncuska "' przektadach (1919); L. Staff, Liryc) francusc)' (1924); A. L. Czerny, Antologia nourej liryki francuskiej (1925) oraz późnicjsze antologie S. Napierskicgo: Od Bandelairéa do nadrealistón (1933) i Lirycy frumcusc) (1936-37) - Literatura polska XX wicku. Przew'odnik encyklopedycany', red. A. Hutnikiewicz, A. Lam, t. 2. Warszawa 20(03, s. 471.

${ }^{+}$Z jego syntetyzujących prac o wspólczesnej poezji francuskicj uależy wymienić jeszcze: Surrealizm. Teoria i praktyka literacka. Antologia, Warszawa 1973: Od Rimbanda do Eluarda, Warszawa 1973; Dziu'na historia al'angurdy'. Warszawa 1976.

${ }^{5}$ Z rozmowy przeprowadzoncj 8 lutego 2005 w mieszkaniu autorki w Warszawie przez A. Legeżyńska i M. Telickiego. Tekst autoryzowany.
} 
Gdy liście w rzekach poruszają się jak uszy stonia,

Liście platanów, ciężkie kasztany ${ }^{(}$.

Etap paryski był dopicro przed nią. Jednak juz wtedy od jednego z niespokojnych duchów z Montmartre'u nauczyła się przede wszystkim długiej frazy, charakterystycznej dla jej kolejnych tomów, oraz bacznej obserwacji świata. Nauıczyla się także (nie tylko od Cendrarsa, ale i z wlasnego życiowego doświadczenia), że optymistyczny obraz „czystego nieba” zawsze musi być przetykany niepokojem. Trzeba zwrócić uwagę na to, że mentalna mapa kosmosu, tworzona w wierszu przez podmiot zdecydowanie skoncentrowany na percepcji wzrokowej, dąży do frazy o „pracy nad Końcem Świata”. Hartwig postępuje często podobnie: próbuje zagarnąc jak najwięcej świata, zintegrować pozornie sprzeczne plany zewnętrznej natury z wewnętrzną kulturą. Niby mimochodem wprowadza ciemmy i niepokojący punkt - chwyt tak charakterystyczny dla surrealistów. Częściej czyta się jednak Cendrarsa (i podobnie I Iartwig) przez pryzmat obrazowości wolnej od trudnych doświadczeń, jako poetę tego nurtu nowoczesności, który swą uwagę skupia na „upajaniu się bogactwen życia" ${ }^{\text {7 }}$ Przypuszczam, że szczegółowa i rzetelna analiza dzieł autora Wielkanocy " Nou'y'm Jorku i jego polskiej thumaczki dowiodłaby tezy wręcz odwrotnej, mającej swe źródła w koncepcjach romantycznych: poezja łączy powierzchnię ladu z ukrytą pod nią świadomością niezrozumiałego strachu. Połączenie, które każe pytać: .Jak to się dzieje, że jest we mnie radość i ból równocześnie". Julia I Iartwig da wyraz tej dwoistości (słowo znaczące w kontekście jej twórczości) wiele lat później we wspomnieniu zamieszczonym w dziennikach Zau'sze pouroty:

Wspomnienie z dzieciństwa tuż po śmierci Mamy. (...) Pamiętam, jak stałam przy stole, pod górnym świattem elektrycznym i wszyscy patrzyli na mnie, albo tak mi się wydawało. I pamiętam równoczesne uczucie rozdwojenia: własny smutek i zarazem niepewność, jak się mam zachować w nowej roli sieroty budzącej wspólczucie. I świadomość wstydu równocześnie, że mogę o tym myśleć w takiej chwili. (...) Podobieństwo jednej z moich próz poetyckich o cierpiącym dębie z prozą Michanx. Skąd ta zbieżność? Skąd przekonanie, że gdyby drzewo cierpiało, cierpialoby na miarę swej siły - patetycznie. Ta sama pokusa wyobraźni $u$ niego i 1 mmie".

Niezwykłe jest zestawienie obrazu śmierci matki, cierpiącego drzewa i swej wyobraźni z wyobraźnią Michaux. Odbija się w nim wiara w moc slowa przewyższającą żywiol śmierci, i ufność, że istnieje wspólnota poetów, reagująca empatycznie na różnorodne zdarzenia

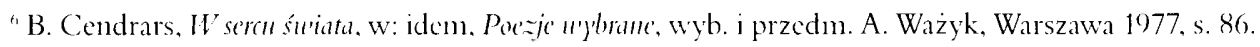

A. Ważyk, Od Rimbanda do Ellarda, Warszawa 1964, s. 159.

'J. Hattwig, Zan's z' pourroty. Dziemniki podrózy, Warszawa 2001, s. 261-262. 


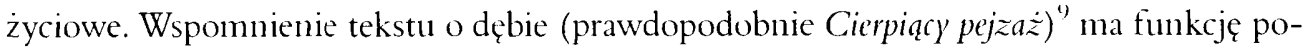
dwójną: występuje jako metafora cierpienia, w tym wypadku odniesionego do matki, i jako łącznik między twórczością oryginalną a inspiracjami translatorskimi.

Blaise Cendrars (a także Max Jacob, Guillaume Apollinaire i wspomniany wyżej Michaux) dali też Julii Hartwig lekcję gatunku w Polsce mało znanego i popularnego: prozy poetyckiej. Jerzy Kwiatkowski charakteryzuje go następująco:

W Pocmacié odczytany'm na ślıbie André Salmona [autorstwa Apollinaire'a] (...) jesteśmy w głównym nurcie tego wielkiego zjawiska. Począwszy od „obniżenia tonu" (przy jednoczesnym jego dynamizmie), od dopuszczenia zwykłej — wlaśnie! - „prozy życiowej” do tematyki wiersza, poprzez typ słownictwa, okolicznościowy charakter, migawkowość w ujmowaniu fragmentów przedstawionego świata, po whitmanowski typ wolnego wiersza - wszystko wskazuje na to, że jedıa z zasadniczych przemian poezji XX wieku juz się rozpoczęła - jak na to zwróciła już uwage Julia Hartwig - najśmielsze realizacje tego prozaicznego nurtu to poematy Cendrarsa ${ }^{\prime \prime}$.

Formę prozy poetyckiej zastosowala - wtedy jeszcze bez teoretycznej świadomości towarzyszącej dalszym poszukiwaniom - w debiutanckim wystąpieniu wraz z grupą kolegów, małej ksiązeczce zatytulowanej Whbór uierszy poetóu lubelskich. Zaprezentowanych tam tekstów nie można z pewnością porównać z późniejszymi poematami prozą, zebranymi w tomie Móu'iqc nie tylko do siebie, przywiązanie do gatunku - wyrażone zresztą expressis verbis" - pozostało. Michaux realizowat inny, bardziej dramatyczny i „ciemny” model poematu prozą, drugą stronę rozważań Cendrarsa.

Nie byłoby jednak dogłębnej znajomości artystów patronujących rodzącemu się w literaturze kubizmowi i nadrealizmowi, gdyby nie otrzymane od rządu francuskiego stypendium, dzięki któremu początkıjąca poetka wyjeżdża do Paryża. Wtedy była jeszcze autorką reportaży do „Odrodzenia” i „Kuźnicy”, a jej kandydaturę do stypendium zaproponował Stefan Ź́lkiewski ${ }^{12}$. Razem z nią jechal pierwszy mąż, również urodzony w Lublinie, później znany krytyk filmowy - Zygmunt Kałużyński. Pierwszy pobyt we Francji, podczas którego pracowala w polskiej ambasadzie, trwał trzy lata: od 1947 do 1950 roku. Szansa byla niepowtarzalna: w stolicy światowej kultury mogla spotkać wielu twórców polskich (wśród

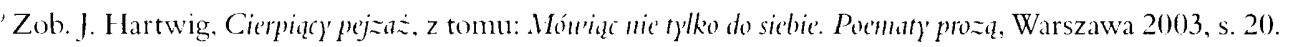
1" J. Kwiatkowski. Istęp do: G. Apollinaire, Ityór poezji. Wroclaw 1975, s. LXXXVIII.

"..Pocmat prozą okazal siç jakby dla mnic stworzony. Zadchiutowałan w turolegii poctún lubelskich dwoma mlodzieńczymi pocnnacikami, nicjasno rozumicjąc jeszcze wówczas, czym odznacza siç ta forma i jakic są jej tajemnice. Przzez wicke lat wracalam do nicj. kiedy tego ode mnic żądalı, i traktowałam ją na równi z tym, co nazywany wierszem" (J. Hartwig. Postow'e do zbioru Mómią mie tylko do siebie, op. cit., s. 141.

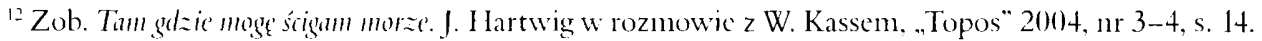


nich Miłosza), ale zapoznała się również z egzystencjalizmem. Niewątpliwie przyszła autorka Poźegnań korzystata z atmosfery nowoczesnego miasta, Paryża, jakim je widzial I Ienri Cartier-Bresson, które nie tylko oferowało jej dostęp do tych samych bibliotek, z których korzystali Apollinaire i Jacob, ale również pokazywało oblicze nieznane przybyszowi z kraju komunistycznego. Autorka Obcou'ania powtarzała doświadczenie wielu artystów ze Wschodı, którzy, mówiąc stowami wiersza,

zaawanturowali się z Bialorusi do Paryża

gdzie według wszelkiego prawdopodobieństwa powinni byli zginąć w thumie artystów przybylych z całego świata ${ }^{13}$.

Julia I Iartwig była co prawda tylko obserwatorka paryskiego życia, nie zamierzała tak jak opisywany malarz Chaim Soutine robić w stolicy Francji artystycznej kariery. Podobieństwo do jej podróży wykazıje natomiast — dużo krótszy co prawda - wyjazd najbardzicj znanego lubelskiego poety, Józefa Czechowicza. Autor Kamienia przebywał w kraju Ludwików przez kilka miesięcy w 1930) roku i poświęcil jej część swoich wierszy. Co znamienne, Czechowicz zdaje się być w Paryżu wylącznie turystą, nie poetą, choć jedyny wiersz poświęcony stolicy jest wyraźnie naznaczony inspiracją Norwidowską ${ }^{1+}$. Można przeprowadzić paralelę między poetami ziemi lubelskiej, gdyż obojgu wyjazd umożliwiło stypendium (Czechowicz otrzymal je głównie dzięki poparciu Wilama Horzycy) ${ }^{15}$, jednak Julia I Jartwig zdecydowanie bardziej skorzystała z oferty naukowej, nie tylko pogłębiając swą wiedzę o francuskim modernizmie w poezji, co miało późnicj wpłynąć na jej twórczość oryginalną, ale dokonala również wstẹpnych rozpoznań do monografii Guillaume’a Apollinaire’a, do której powrócę w dalszej części artykułu.

Po powrocie do kraju i rozpadzic krótkiego, nicudanego małżeństwa z Kalużyı́skim, Julia Hartwig podtrzymywała swoje związki z Francją na różne sposoby. Kontynuowala prowadzona jeszcze przed wyjazdem kronikę francuską - teraz juz z pozycji osoby znającej realia Paryża - choć częściej, co może być powodem zdziwienia, zajmuje się tematami lokalnymi, wsią i krajobrazem polskim. Nie zaniedbuje jednak tłumaczeń: przekłada Kommnistón' Aragona, Colas Brengnon Romain Rollanda, wiersze Paula Eluarda, Jacoba i Apollinaire'a. Natomiast w 1954 jej drugim mężem zostaje Artur Międzyrzecki — odtąd stanowić będą nie tylko wyjątkowe matżeństwo poetów, ale i duet translatorski (a po urodzeniu córki Danieli także bajkopisarski). W jednym ze wspomnień Julia Hartwig powie, ze nawet podczas pobytu we Francji nie poznala tylı Francuzów, ilu dzięki szerokim kontaktom swojego męża - pisarza aktywnie włączającego się w prace Polskiego Związku Literatów i polskiego PEN-Clubu. Wspólną literacką pasją byla dla nich poezja Apollinaire'a, określa-

1'J. Hartwig. Rozpozmantanic Soutime'a, z tomu: Zobacome. Kraków 200(), s. 86.

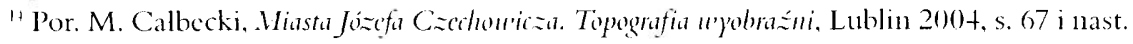

15 Zob. ibidem, s. 30. 
jącego samego siebie jako ,poetę niekochanego”, a przez innych docenionego (szczególnie po śmierci) jako pierwszej wielkości awangardzistę. Apollinaire okazal się dla nich atrakcyjny z wielu względów. Po pierwsze, decydująca mogła być mała znajomość jego dzieła wśród polskiej publiczności literackiej. Kiedy bowien w 1956 i 1958 Hartwig przebywała po raz kolejny we Francji (po tej wyprawie pozostal ślad w postaci artykułów w „Nowej Kulturze" ${ }^{\text {in }}$, spotykała się nieustannie z jednym pytaniem:

Francuzi bardzo się dziwili, że w literaturze polskiej nie ma książki o Guillaumie Apollinaire. „Jak to, więc nikt w Polsce nie zbiera dokumentacji do barwnego, ciekawego życia znakomitego poety, którego matka nazywała się Kostrowicka?"17.

Drugi argument był niejako automatycznie zawarty w pytaniu - skoro poeta jest „znakomity, wybitny”, a temu zaprzeczyć nie sposób, warto przygotować biografię, która przybliży jego sylwetkę. Tym bardziej, że polskie korzenie wydawały mu się powodem do dumy, gdy wymieniał siebie, obok Conrada i Przybyszewskiego, w grupie polskich pisarzy niepiszących po polsku. Trzecia kwestia, także istotna: dlaczego tak wiele pozostaje tekstów nieprzethumaczonych? Autor Alkoholi tworzył utwory nawiązujące do różnych stylów (od początkowych zainteresowań symbolizmem po utwory pre-surrealistyczne), poruszające różne tematy (by wspomnieć zwierzęce motywy Śl'ity Orféusza, a przy nich wiersze do Madelaine), czy wreszcie zamykające żywioł mowy w zmiennych rozwiązaniach edytorskich (czego dobitnym przykładem są najlepiej chyba znane Kaligramy'). Nie może dziwić, że thumacze o nieco innych temperamentach i upodobaniach podzielili pracę nad utworami Apollinaire'a:

Thumaczenia to bardzo udatne - pisal o Nou'ych przektadach Julii Hartwig i Artura Międzyrzeckiego wydanych w 1973 roku Jerzy Kwiatkowski w wielı wypadkach przewyżsające te, które istniały dotychczas, przy czym para tlumaczy (...) trafinie rozdzieliła między siebie role: Julia Hartwig przekłada wiersze wolne i bardziej sprozaizowane, Artur Międzyrzecki (...) raczej utwory nawiązujące do regularnej wersyfikacjils.

Przekłady tekstów poetyckich twórcy Hertyka i $S$-ki miały być zatem w pewien sposób paralelne względem twórczości oryginalnej. Jeżeli bowiem Julia Hartwig sięga po wiersz wolny i prozę poetycką, to również — jak sądzę — po to, by skonfrontować ją ze swymi dokonaniami na tym polu i wzbogacić swoje utwory o zdobycze warsztatu stawnego awan-

"Zob. J. Hartwig, Paryź po széściu latad, .,Nowa Kultura” 1956, ur 15, s. 2 (cz. 1): nr 29, s. 1-2 (cz. 2).

"J. Hartwig. Śladumi .Apollinaire'a, .. Nowa Kultura" 1958, 11 r 31, s. 1.

I. Kwiatkowski. op. cit.. s. CLXXIII. 
gardzisty. Jej własnej twórczości także towarzyszy przecież duch dwoistości, jaki dostrzega w dziele Apollinaire’a. We wstępie do Nou'ych przekładón tłumacze zauważąą bowiem „dwa profile" twórczości francuskiego poety: jeden odpowiada za biegun tradycjonalistyczny, drugi - za nowatorski. Pierwszy „przemawia jasnym”, podczas gdy drugi — „ tamiącym się glosem" ". Rzecz znamienna, ze debiutancki tom wierszy Hartwig Pożegnania (wydany w 1956 roku), pozornie najprostszy i najmniej wyrafinowany artystycznie, wydaje się pod tym względem terminować w szkole apollinairowskicj - ukazał bowiem podwójną twarz krytykom. Ryszardowi Matuszewskiemu objawia się spóźniona debiutantka jako autorka poezji mniej skomplikowanej intelektıalnic, Michat Glowiniski twierdzi natomiast, że

Julia Hartwig należy (...) do tego grona poetów, których się zwykło nazywać intelektualnymi ${ }^{20}$.

Nie ma więc zgody co do jednoznacznej oceny dzieł poetki - i ocenę tę można przenieść na dalsze etapy rozwoju twórczości - co świadczy o niełatwej ich klasyfikacji ze względu na walory poetyckic.

Apollinaire - najbardziej wytrwały towarzysz francuskiej przygody autorki Obourania — stał się również bohaterem literackicj monografii. Nietypowej, gdyż w miejsce ścisłej naukowości wprowadza narrację - co prawda z bardzo rzetelnie przygotowanym zapleczem biograficznym, ale i miejscem na szeroki domniemany rysunek psychologiczny postaci i swobodną rekonstrukcję kulturalnego tla życia w Paryżu na początku wieku. Swój projekt, szeroko i ambitnie zakrojony oraz - co ważne - zrealizowany z dobrym skutkiem, pisarka objaśniała na łamach „Nowej Kultury”:

Biografia literacka, tie romancée, to rodzaj traktowany z pogardą przez pisarzy, uważany za podlejszy gatunek literatury. (...) Czy można [jednak| znaleźć przyzwoitszy sposób zaspokajania ludzkiej potrzeby ciekawości, która szuka sobie ujścia w lekturze biografii historycznych? Nie mam tej pewności, a jednak rozpoczęłam książkę o Apollinairze i to nie z żądzy zysku lıb sławy, lecz z prawdziwej lıdzkiej sympatii do człowieka i przywiązania dla jego poezji²!

\footnotetext{
"Podsumowując swe rozważania, autorzy sami dają wskazówkę do przeprowadzania paraleli miçdzy ich twórczością a twórczością autora Listól do Madeluinc. pisząc: .Dwa profile Apollinairc'a, w ruchu, nicpokojąco zmicune, towarzyszą każdemu, kto sięgnic do jego legendy i twórczości"-J. Hartwig. A. Między-

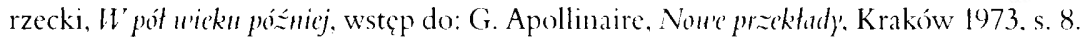

2" Różnice między odczytaniami są zresztą tak duże. że wydają siç antonimicznie ulożoną listą. Równolegle odczytanic interpretacji krytyków oraz spojrzenie z dluzszej perspektywy historycznoliterackicj mogloby stanowić material na cickawy esej. Przywolywanc prace to: R. Matuszewski. |sprawozdanic w dziale Liryka i poemat]. .Rocznik Literacki” 1956, s. 47: M. Cilowinski, Liryka Julii Hartwigs, ..Twórczość” 1956. nr 8 , s. $158-161$.

${ }^{21}$ J. I Iartwig, Śladami Apollinaire'a, „Nowa Kultura” 1958, m. 31, s. 1.
} 
Jeżeli wierzyć poetce - a nie mamy podstaw, by tego nie czynić — trzeba założyć, że kierowała nią humanistyczna dociekliwość, która doprowadziła ją inną drogą do naukowego obiektywizmu. Monografia Apollinaire'a jest bowiem efektem wielogodzinnych rozmów z tymi, którzy pamiętali poetę, efektem poszukiwań dokumentów zaświadczających o wydarzeniach z jego życia, zbiorem anegdot i wreszcie próbą polączenia biografii osobistej z biografią twórczą (tak, by interpretacja dzieła oświetlała życie i vice versa). Sukces książki (którego miarą może być przekład na kilka języków, w tym francuski) polega jednak na czymś więcej. Zręczne lączenie wydarzeń z różnych lat, przy równoczesnym zachowaniu kompozycyjnego porządku, pozwala na zobaczenie szerokiej panoramy życia i osadzenia w jej kontekście różnorodnej twórczości. Panoramiczne widzenie kontekstu wydatnie wzmacniają opowieści o środowisku, z którym stykał się „poeta niekochany”: obserwujemy więc wybryki Alfreda Jarry, rozterki Picassa przy tworzeniu Panien z Auvinionu, moralıe dylematy Maxa Jacoba, który odłącza się od grupy dawnych przyjaciól, by koniec życia spędzić w opactwie benedyktyńskim Saint-Benoit i ginie w Drancy. Obserwujemy aktywne grono malarzy: Soutine’a, Modiglianiego, Delaunaya, Marie Laurencin (miłości Apollinaire’a), Rousseau Celnika i rodzący się kubizm, przeszczepiany na literaturę. Równocześnie obserwujemy nieszczęśliwe związki miłosne Apollinaire’a, perypetie po oskarżeniach o obrabowanie Luwru i prace na niskoplatnych etatach w kolejnych czasopismach. Przez zręcznie prowadzoną narrację przebija ogrom pracy dokumentacyjnej, ale i znajomość wspólczesnej Francji, która dziedziczy po rówieśnikach Michaux klimat rozrywki intelektualnej zgodnie wspólistniejącej z rozrywkami cielesnymi.

Zostawmy jednak Apollinaire’a, z przykrą świadomością nieadekwatności opisu w stosunku do miejsca, jakie zajmuje w dorobku autorki Nie ma odpouriedzi. W wielu późniejszych wierszach Julia Hartwig okazuje swoje przywiązanie do tej fascynującej postaci, prawdziwy hołd oddaje mu w wierszu z tomu Bez pożegnania:

(...) Przebudzić się — to nie każdemu dane

Idąc nasłuchiwal w sobie tego śpiewu

z którego rodziło się przymierze ze światem

Pocisk który przebił mu czoło w okopach Szampanii

byl jak gwiazda która go naznaczała ${ }^{22}$.

W poetyckim hołdzie zamyka się mikrokosmos egzystencji poety: gwiazda, która namaszcza go na poetę, jest równocześnie gwiazdą śmierci, przybrana ojczyzna, za którą nie musiał, ale chcial walczyć, staje się krajem schylku życia. A jednak poetyckie szaleństwo daje mu silę do jednoczenia się ze światem i symbolicznego przebudzenia: do poznania natury poezji nowej, przemieniającej — według formuly Rimbauda — twórcę w jasnowi-

22 J. Hartwig, Whotdzic Apollinariouri z tomu $B c=$ pozegnania, Warszawa 2004, s. 9. 
$\mathrm{dza}^{23}$. Jest to równocześnie przebudzenie ku lepszemu światu i ku rzeczywistości śmierci, możliwej do poznania tylko dzięki poezji.

Julia Hartwig jest autorką drugiej jeszcze monografii literackiej - mniej znanej, ale także ważnej ze względu na nikłą znajomość opisywanego twórcy. Rys życia i twórczości Gerarda de Nervala pozostal jednak wydarzeniem jednorazowym. Nerval - romantyk, który stal się duchowym patronem surrealistów - był poetce potrzebny wylącznie, jak się zdaje, do tego, by lepiej zrozumieć nadrealizm. W grę wchodził również przywołany wyżej czynnik ludzkiej cickawości przetransponowany na znaki literackie oraz zaznajomienie polskiego czytelnika z barwną postacią literatury francuskiej. Od Nervala poetka nie wzięla jednak literackich pomysłów tematycznych ani kompozycyjnych, nie przywoływala go w poezji ani nie wracala do niego w innych swoich tekstach.

Praca translatorska i monografie stanowia najbardziej obszerny dzial w ramach kulturowego przerzucania słów ponad granicami państw (o których Szymborska słusznie pisała, że są nietrwałe). Mijają lata, podczas których nowe tomy poetyckie ciągle przeplatają się z nowymi przekładami (ogłaszanymi bądź osobno, bądź w antologiach). I Iartwig, która inteligentnic podgląda życiorysy innych pisarzy, powoli dojrzewa do tego, by umożliwić czytelnikom podejrzenie jej biografii - luźnych notatek z podróży między Paryżem, Nowym Jorkiem a Warszawą. W formic Zau'sze pourroty. Dzicmniki podróży będą nieco podobne do opublikowanego w 1980 roku Dzicmika amerykanskiego, nazwanego przez Ryszarda Kapuścińskiego jedną z najlepszych książek reportażowych XX wieku.

Dzienniki (czy raczej quasi-dzienniki) Zau'sze pou'roty mają podwójnego patrona: z jednej strony jest nim literatura, z drugiej - nurt życia codziennego. I Iartwig celuje bowiem w obserwacji otaczającego ją świata: czeka na listy od córki, opisuje swoje zakupy, wspomina o umówionej wizycie u lekarza. A równocześnie - bez zbytniej nadętości i sztuczności — przywolıje szereg nazwisk czolowych twórców literatury polskiej, czasowo bądź na stałe przebywających w Paryżu. Ważnym miejscem na mapie polskiej emigracji było wówczas Centre dı Dialogue — ośrodek prowadzony przez księży pallotynów:

Niełatwo byłoby wymienić nazwiska wszystkich prelegentów występujących (...) w Centre, począwszy od Czesława Miłosza, Stefana Kisielewskiego, Zbigniewa I Ierberta i Konstantego Jeleńskiego, po Jerzego Turowicza, Stanisława Stommę, Wlodzimierza Odojewskiego, Andrzeja Micewskiego czy Leszka Kolakowskiego i Krzysztofa Pomiana. Zaiste, byl to rodzaj arki Noego, ze zwierzętami najróżniejszych rodzajów i maści. Już kilka rzuconych tu z pamięci nazwisk wystarczy, by zdać sobie sprawę, jak rozległy był zasięg tematyczny wieczorów w Centre dn Dialogne: filozofia, zagadnienia wspótczesności polskiej, literatura, poezja $a^{2+}$.

${ }^{23}$ Zob. A. Rimbaud, List jasmonidza, w: A. Miçdzyrzecki, Rimband, Apollinare i immi, Warszawa 1988, s. 74.

${ }^{2+} \mathrm{J}$. Hartwig, Rodzaj. Alki Noego (tekst dostępny przez luttp://www.recogito.l.pl/recogito_cd/wiara3.htm). 
Zapiski z Arki Noego, jak Centre du Dialogue nazywa Julia Hartwig, rozciągają się na ciągle nowe odkrywanie malarstwa, podziw dla europejskiej myśli o kulturze, ale i na przeczytane ostatnio lektury, rozmowy o wspótczesnej Polsce i codzienne kobiece krzątactwo (by użyć terminu Jolanty Brach-Czainy). Tygiel tematów, spostrzeżeń, opinii i osób pokazuje życie polskiego intelektualisty na przestrzeni lat osiemdziesiątych i dziewięćdziesiątych - jakby mimochodem otrzymujemy obraz zmian w spoleczeństwach zachodnich, mamy okazję do porównań i analiz, śledzimy nieustający proces przemieszczania się pozycji w obrębie kultury.

Książka Zau'sze pou'roty stanowi też swoistą klamrę dla moich rozważań. Elementem jednoczącym jest podróż, która dla autorki Wolnych rąk wydaje się kategorią kluczową. Wyruszając na francuskie stypendium w 1947 roku, Julia Hartwig nie zdawała sobie być może sprawy, że wyrusza w podróż nieustającą, która zaprowadzi ją nie tylko na drogi Normandii czy Prowansji, ale również na amerykańskie uniwersytety. Wyruszyła również na wyprawę o wiele poważnicjszą: do źródeł nowoczesnej poezji, poprzez zaułki sztuki lamiącej reguły, wśród obrazów i słów. Rozpoznawala ten teren przez wlasne poszukiwania liryczne, inspirowane, co starałem się pokazać, wzorami francuskimi, oraz przez medium thumaczeń - przyswajając obce teksty mowie polskiej, tak jak czynili to już mistrzowie renesansowi. Wpisala się w rozpoczęty przez nich proces przenikania pierwiastków romańskich do słowiańskiej kultury i twórczo go wykorzystala.

Wypowiedziane przez pierwszego naszego liryka słowa: „Ronsardun vidi” stanowią chyba początkowy moment sprzęgnięcia losów polskiego wierszopisarstwa z poezją narodu, który wydal autora Sonetóu do Kasandry. (...) Sformulowanie Kochanowskiego otwiera bodaj na dlugo nieprzerwany — by sparafrazować Boya - romans polskich poetów z liryką francuską ${ }^{25}$.

Julia I Iartwig stanowi — przynajmniej do tej pory — jedno z ogniw końcowych.

$\Rightarrow$ M. Glowiński. Od ll iktora Hugo do Aruguma, .Nowa Kultura” 1957. ur 6. s. 7. 